\title{
Sedimentary pyrite as a potential sulfur source for MVT Pb-Zn deposits: A case study of the Huodehong Pb-Zn deposit, South China
}

\author{
KAI LUO AND JIA-XI ZHOU*
}

School of Earth Sciences, Yunnan University, Kunming 650500, China (*Corresponding author, Email: zhoujiaxi@ynu.edu.cn)

Sedimentary pyrite plays an important role in the formation of MVT Pb-Zn deposits, but there are few related studies. In the western Yangtze Block, SW China, there are $>400$ carbonate-hosted epigenetic $\mathrm{Pb}-\mathrm{Zn}$ deposits, which form the giant Upper Yangtze $\mathrm{Pb}-\mathrm{Zn}$ metallogenic province with $>26 \mathrm{Mt} \mathrm{Pb}+\mathrm{Zn}$ base metals. Among these $\mathrm{Pb}-\mathrm{Zn}$ deposits, the Huodehong Devonian carbonate-hosted $\mathrm{Pb}-\mathrm{Zn}$ deposit is characterized by large amount of the coexisting sedimentary pyrite and low $\delta^{34} S_{\text {sulfides }}$ values $(-17$ to $-11 \%$ ), which are significantly distinct from those of most other $\mathrm{Pb}$ $\mathrm{Zn}$ deposits $\left(\delta^{34} \mathrm{~S}_{\text {sulfides }}=2-25 \%\right.$ o $)$ in this province. Hence, the Huodehong deposit provided an ideal case study for revealing the role of sedimentary pyrite played in the formation of MVT $\mathrm{Pb}-\mathrm{Zn}$ deposits.

Mineralogical study identified large amount of pyritic stromatolites, which show zoning structure with micro-nanosized filamentous/tabular pyrite, stromatolites, organic matters, goethite and dolomite in core, and coarse-grained marcasite, pyrite and sphalerite in rim. This suggests that sedimentary pyrite is an important factor that determined the mineralization location, which means the hydrothermalreworking mineralization occurred in the Huodehong deposit. NanoSIMS in-situ $\mathrm{S}$ isotope analysis shows that $\delta^{34} \mathrm{~S}$ values of sulfides (sedimentary and hydrothermal pyrite) range from -23 to $-7 \%$, of which sedimentary pyrite grains have $\delta^{34} \mathrm{~S}$ values ranging from -23 to $-10 \%$, hydrothermal pyrite grains have $\delta^{34} \mathrm{~S}$ values ranging from -18 to $-7 \%$. This means that sedimentary pyrite may provide the main reduced sulfur for the formation of the Huodehong $\mathrm{Pb}-\mathrm{Zn}$ deposit through hydrothermal-reworking, although bacteria sulfate reduction (BSR) may also provide some reduced sulfur.

This study demonstrates that sedimentary pyrite acted as a potential sulfur source and the mineralization locationdetermined factor in the formation of MVT $\mathrm{Pb}-\mathrm{Zn}$ deposits, which provides new insights for understanding the origin and ore exploration of MVT Pb-Zn deposits worldwide.

This work is supported by National Natural Science Foundation of China (41872095, U1812402, 41430315). 